\title{
Adsorptive Removal of Cobalt (II) and Chromium (III) from Aqueous Solution onto Citrus Limon Leaves Powder
}

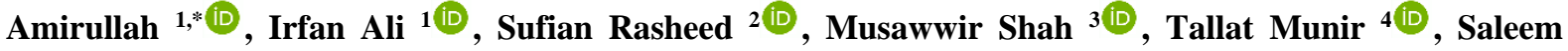 \\ Nawaz $^{3}$ iD \\ 1 Department of Chemistry, Hazara University Mansehra, KPK, Pakistan; amirullah@hu.edu.pk (A.), \\ irfantank245@gmail.com (I.A.); \\ 2 HEJ Research Institute of Chemistry, University of Karachi, Sindh, Pakistan; sufianrasheed75@iccs.edu (S.R.); \\ 3 Department of Chemistry, Islamia College Peshwar, KPK, Pakistan; mosawirshah@gmail.com (M.S.), \\ saleem.nawaz@icp.edu.com.pk (S.N.); \\ 4 Department of Chemistry and Chemical Engineering, Beijing University of Technology, Beijing 100124, China; \\ Ch023tm@kust.edu.pk (T.M.); \\ * Correspondence: amirullah@hu.edu.pk;
}

Received: 27.11.2020; Revised: 7.01.2021; Accepted: 12.01.2021; Published: 19.01.2021

Abstract: The growth of heavy metals in wastewater is a widespread concern that affects thousands of lives and spread diseases worldwide. Its extraction is subject of concert from last few decades. Looking forward in the current study, Citrus Limon leaves were used as an adsorbent for the Biosorption of $\mathrm{Co}$ (II) and $\mathrm{Cr}$ (III) in a batch system. Citrus Limon leaves were brought from the local garden of Amakhel, Tank, Pakistan. The removal process of $\mathrm{Co}(\mathrm{II})$ and $\mathrm{Cr}(\mathrm{III})$ was examined under different conditions of $\mathrm{pH}$, contact time, and initial concentration to get the optimum condition. It was found optimum contact time for $\mathrm{Co}$ (II) and $\mathrm{Cr}$ (II) was 20 and 10 minutes. By the increase of concentration of adsorbate, the value of $\mathrm{q}_{\mathrm{e}}$ was investigated for $\mathrm{Co}(\mathrm{II})$ and $\mathrm{Cr}(\mathrm{III})$ at $20^{\circ} \mathrm{C}$. The optimum initial concentration for $\mathrm{Cr}$ (III) and $\mathrm{Co}$ (II) was $60 \mathrm{ppm}$ and $40 \mathrm{ppm}$, respectively. The optimum shaking power for $\mathrm{Cr}$ (III) and $\mathrm{Co}$ (II) was found to be $150 \mathrm{rpm}$ and $120 \mathrm{rpm}$, respectively.

Keywords: Citrus Limon; heavy metal; biosorption; adsorbate; adsorbent.

(C) 2020 by the authors. This article is an open-access article distributed under the terms and conditions of the Creative Commons Attribution (CC BY) license (https://creativecommons.org/licenses/by/4.0/).

\section{Introduction}

The term heavy metals refer to any metallic element with a density greater than $4 \mathrm{~g} / \mathrm{cm}^{3}$. Zinc $(\mathrm{Zn})$, nickel $(\mathrm{Ni})$, copper $(\mathrm{Cu})$, chromium $(\mathrm{Cr})$ lead $(\mathrm{Pb}), \operatorname{cobalt}(\mathrm{Co}), \operatorname{vanadium}(\mathrm{V})$, mercury $(\mathrm{Hg})$ and cadmium $(\mathrm{Cd})$ are naturally occurring heavy metals in the environment [1]. $\mathrm{Pb}, \mathrm{Cd}, \mathrm{Ni}, \mathrm{Cr}$, and $\mathrm{Hg}$ are the heavy metals that are dispersed in the environment due to soil erosion in agricultural and industrial processes. In non-industrial areas, the major causes of heavy metals are automobiles [2]. Heavy metal deposits are found in the contaminated environment, which may accumulate in microorganisms, aquatic flora, and fauna, which in turn, may enter into the human food chain and result in health problems. These metals are harmful to an organism. They are non-degradable due to which they have a special attraction. Various methods are used to remove heavy metal from wastewater, such as membrane filtration, ion exchange, ion exchange, chemical precipitation, carbon adsorption, and coprecipitation/adsorption [3]. These methods are ineffective, especially when metals in low concentration or highly expensive. Adsorption is one of the most effective, environmentally friendly, and low-cost methods used to remove heavy metals from water. 
Chromium is a transition metal and the first element of the group (VI) and paramagnetic above $38^{\circ} \mathrm{C}$. Its common most common oxidation states are +3 and $+6 . \mathrm{Cr}(\mathrm{III})$ is the $22^{\text {nd }}$ most abundant element in the earth's crust, having three stable isotopes $\mathrm{Cr}^{52}, \mathrm{Cr}^{53}$, and $\mathrm{Cr}^{54}$. Among them, $\mathrm{Cr}^{52}$ is the most stable, and its natural abundance is $83.789 \%$ [4]. $\mathrm{Cr}$ is discharged into the environment from various sources. The sources included electroplating, leather tanning, textile industries, volcanic eruption, metal finishing, nuclear power plants, and chromate preparation. The toxicity of chromium is not that effective up to the permissible limit. However, when that limit exceeds it, it is harmful to plants, animals, human beings, human kidneys, and the liver. At the same time, low concentration causes skin irritation and ulceration [5]. A high concentration of $\mathrm{Cr}(\mathrm{III})$ causes cancer in the digestive tract and lungs [6].

Co is a transition element that belongs to the first transition series lying between iron and nickel. Naturally, $\mathrm{Co}$ (II) exists in a single isotopic from $\mathrm{Co}^{59}$. The common oxidation state of cobalt is +2 . Cobalt(II) was introduced into the environment through various sources, i.e., from industrial effluents, acid mining, urban wastewater plant. $\mathrm{Co}$ (II) can also be exploited from metallurgy, mining, pigments, and nuclear power plants [7]. It is also discharged from industries such as petrochemical, alloy manufacturing industries [8]. Cobalt ions are toxic and cause numerous health issues in plants, animals, and human beings. Co(II) exposure causes several harmful effects like neuro toxicological disorder, cancer, and genotoxicity. The cobalt presence in the environment leads to numerous health troubles such as vomiting, low blood pressure, hair loss, and bone defects [9].

The extensive increase in the expansion of industrialization causes water pollution and has far-reaching effects on the environment. These activities result in the discharge of various chemicals, and water sources get contaminated [10]. It is necessary to remove the heavy metal from water bodies. Different conventional methods are used to remove heavy metals from wastewater, such as ion exchange, reverse osmosis, filtration, and adsorption.

Recently, several methods have been studied for the efficient elimination of heavy metals from wastewater. Adsorption is a suitable technique for the exclusion of heavy metals from wastewater [11]. Adsorption is a process where the substance of dissolved solid sticks on the solid surface from the liquid, i.e., the liquid's dissolved solids is accumulated on the solid surface through physical or chemical interaction. [12]. Adsorption is the conservative method for removing heavy metals and has several drawbacks, such as sludge. Biosorption involves a solid part (biosorbent) and a liquid part (water having dissolved adsorbate). The heavy metals are accumulated on the adsorbent surface through physio-chemical ways. Due to the greater affinity of heavy metals toward adsorbent, efficient removal occurs from wastewater. The method has advantages, i.e., low cost, high efficiency; no extra nutrients are acquired [13].

Various methods have been performed and available in the literature: Glebioniscoronaria L. and Diplotaxisharra were used as adsorbents for removal of cadmium(II), cobalt(II), and some more inorganic ions from aqueous solutions [14]. They detected that the high adsorption to be at $\mathrm{pH}$ 6.5-7.5. With the rise in adsorbent dose, adsorption efficiency improved at all temperatures. Metal upload capability rises with a rise in the concentration of the initial metal. Sunflower biomass was recycled for the subtraction of cobalt (II) in the batch, and a fixed bed column at the various inlet environments studied [15]. Results showed that the ANN model method was followed to assess the performance. For the removal of $\mathrm{Ni}(\mathrm{II}), \mathrm{Co}(\mathrm{II}), \mathrm{Cu}$ (II), corn silk (Activated) was used, at $25^{\circ} \mathrm{C}$ temperature \& $\mathrm{pH}-6$, the metal uptake was observed maximum. [16]. they effectively reused the adsorbent more than 11 times. Cystoseira indicia was used for the exclusion of $\mathrm{Co}(\mathrm{II})$ and $\mathrm{Cu}(\mathrm{II})$ ions from the aqueous 
solutions via single \& binary methods by various operational parameters (Akbari et al., 2015) [17]. Cocus Nucifera shell powder has been applied and reported to remove four ions [18].

Heavy metals such as $\mathrm{Co}$ (II) and $\mathrm{Cr}$ (III) cause serious problems. The heavy metals removal catches serious attention. The present research work objectives to develop an effective, environment friendly, and low-cost biosorbent for the removal of $\mathrm{Co}$ (II) and $\mathrm{Cr}$ (III) from the water with maximum recovery. For this purpose, Citrus limon leaves were used. Various parameters ( $\mathrm{pH}$, adsorbent dose, contact time, adsorbate concentration, and shaking speed) were studied, which influenced the result of selected heavy metals.

\section{Materials and Methods}

$\mathrm{COCl}_{2} .6 \mathrm{H}_{2} \mathrm{O}, \mathrm{Cr}\left(\mathrm{NO}_{3}\right)_{2} .9 \mathrm{H}_{2} \mathrm{O}$, ammonia (33\%), Dimethyl glyoxime (DMG) solution, $\mathrm{Na}_{2}$ EDTA solution, $\mathrm{HCl}(37 \%)$ and $\mathrm{NaOH}(98 \%)$, and acetone, used in the current study included beakers, spatula, stand, conical flasks, pipettes, cork, cylinder, thermometer, graduated cylinder, pestle, and mortar are used in the current study.

The instruments included UV-Vis Spectrophotometer equipped with $1 \mathrm{~cm}$ path length, Quartz cell (S2100 UV Spectrophotometer, UNICO, USA) Orbital shaker (KJ-201bs, Oscillator, South Korea), Oven (IdO-030E, Daihan Lab Tech Co. Ltd. South Korea), digital balance (ATX 224, Shimadzu, Japan), hot plate and magnetic stirrer (MS-300Hs, Scientific, Ltd. South Korea), Digital pH - meter (3505, Jenway, UK) and heavy-duty electric grinder.

\subsection{Preparation of adsorbent.}

\subsubsection{Collection and pre-treatment.}

Lemon leaves were collected from a local garden of Amakhel, Tank, Pakistan. Lemon leaves were washed with tap water and then dried in sunlight. For complete dryness, it was placed in an oven at a temperature of $50^{\circ} \mathrm{C}$ for 7 hours. The dry lemon leaves were ground using a heavy-duty electric grinder for making their powder.

\subsubsection{Preparation of adsorbate solution.}

$1000 \mathrm{mgL}^{-1}$ of stock solutions of the selected adsorbates were prepared by dissolving $2.20 \mathrm{~g}$ and $7.7 \mathrm{~g}$ of $\mathrm{CoCl}_{2} .6 \mathrm{H}_{2} \mathrm{O}$ and $\mathrm{Cr}\left(\mathrm{NO}_{3}\right)_{2} .9 \mathrm{H}_{2} \mathrm{O}$ respectively in $1000 \mathrm{~mL}$ of double deionized distilled water (DDDW). The dilute solutions were then prepared by using the dilution formula;

$$
C c V c=C d V d
$$

\subsection{Determination of adsorbate concentration.}

\subsubsection{Spectrophotometric determination of $\mathrm{Co}(\mathrm{II})$.}

A series of Co(II) solution were prepared (60 ppm, 50 ppm, 30 ppm, 20 ppm, and 10 $\mathrm{ppm}$. For the Spectrophotometric determination of Co(II) five volumetric flasks $(50 \mathrm{~mL})$ were taken. To each volumetric flask $3 \mathrm{~mL}$ of adsorbate solution, $1 \mathrm{~mL}$ of $1 \mathrm{M} \mathrm{HCl}$ solution, and 6 $\mathrm{mL}$ of acetone were added. The mixture was mixed and stood for a few minutes. Measured the absorbance of the solution at $680 \mathrm{~nm}$ [19]. 


\subsubsection{Spectrophotometric determination of $\mathrm{Cr}$ (III).}

Various samples of Cr (III) solutions were prepared (60 ppm, 50 ppm, 30 ppm, 20 ppm, $10 \mathrm{ppm}), 5 \mathrm{~mL}$ of each prepared $\mathrm{Cr}(\mathrm{III})$ solution were taken in a test tube and $5 \mathrm{~mL}$ of $0.5 \%$ freshly prepared $\mathrm{Na}_{2}$ EDTA was added to the test tube (dissolve $0.5 \mathrm{~g}$ of $\mathrm{Na}_{2}$ EDTA per $100 \mathrm{~mL}$ of distilled water). The test tube was kept in a beaker with boiling water placed on a hot plate for 10 minutes. Then the test tube was made cool, and absorbance was found against $552 \mathrm{~nm}$ [20].

\subsection{Factor influencing the adsorption.}

\subsubsection{Effect of $\mathrm{pH}$.}

For this purpose, $50 \mathrm{~mL}$ of selected adsorbate solution (each having concentration 20 ppm) was taken in eight separate $100 \mathrm{~mL}$ flasks (Volumetric), with $\mathrm{pH}$ ranging from 2 to 13. For the adjustment of $\mathrm{pH}, 0.1 \mathrm{M} \mathrm{HCl}$ solution and $0.1 \mathrm{M} \mathrm{NaOH}$ solution were prepared $0.1 \mathrm{~g}$ adsorbent dose were added to each flask and were shaken at $120 \mathrm{rpm}$ for 2 hours using an orbital shaker. The concentration of adsorbate was determined in the same way as discussed above. The adsorbed amount of adsorbate per unit mass of adsorbent $\mathrm{q}_{\mathrm{e}}$ was measured with the given equation's help.

$$
q_{e}=C i-C f / W \times V
$$

Where $\mathrm{C}_{\mathrm{i}}$ and $\mathrm{C}_{\mathrm{f}}$ are the initial and final concentration of adsorbates before and after adsorption, respectively.

V shows the adsorbates' volume, and W represents the weight (g) of the adsorbent (CLL). Percentage removal was determined using the formula.

$$
\% \text { Removal }=\mathrm{Ci}-\mathrm{Cf} / \mathrm{Ci} \times 100
$$

For obtaining the optimum value of $\mathrm{pH}$, the results were plotted against $\mathrm{pH}$ vs. $\mathrm{q}_{\mathrm{e}}$ and $\%$ removal.

\subsubsection{Effect of adsorbent dose.}

For this purpose, $50 \mathrm{~mL}$ of selected adsorbate solution (each concentration of $20 \mathrm{ppm}$ ) was taken in the eight distinct $100 \mathrm{~mL}$ flasks with an adsorbent dose ranging from 0.1 to $0.5 \mathrm{~g}$, keeping $\mathrm{pH} 2$ for both. The mixture was continuously shaken for 2 hours at $120 \mathrm{rpm}$ by using an orbital shaker. The rest of the procedure was the same as discussed above. The result was plotted as Adsorbent dose (g) vs. qe and \% removal to obtain the optimum value of adsorbent dose.

\subsubsection{Effect of contact time.}

To obtain optimum contact time $50 \mathrm{~mL}$ of selected adsorbate solution (each having concentration $20 \mathrm{ppm}$ ) were taken in six separate $100 \mathrm{~mL}$ volumetric flask with adsorbent dose $0.3 \mathrm{~g}$ and 0.5 (optimized) for $\mathrm{Co}$ (II) and $\mathrm{Cr}$ (III), respectively, on optimized $\mathrm{pH} 2$ for $\mathrm{Co}$ (II) and $\mathrm{Cr}$ (III). The different solutions were shaken for a different period of time, i.e., $10 \mathrm{~min}, 20 \mathrm{~min}$, $30 \mathrm{~min}, 40 \mathrm{~min}, 50 \mathrm{~min}, 60 \mathrm{~min}$, while the orbital shaker's speed was kept at $120 \mathrm{rpm}$. The rest of the procedure was the same as discussed above. The result was plotted as contact time (min) vs. qe and \% removal to get the optimum value of contact time. 


\subsubsection{Effect of initial concentration.}

To obtain the optimum value of initial concentration $50 \mathrm{~mL}$ of selected adsorbate with different concentrations ( $20 \mathrm{ppm}, 40 \mathrm{ppm}, 60 \mathrm{ppm}, 80 \mathrm{ppm}$, and $100 \mathrm{ppm}$ ) were taken in five separate $100 \mathrm{~mL}$ volumetric flask. Optimized amounts of adsorbent dose $(0.3 \mathrm{~g}$ and $0.5 \mathrm{~g}$ for $\mathrm{Co}$ (II) and $\mathrm{Cr}$ (III)correspondingly were added to each flask at optimized $\mathrm{pH}$. Contact time 20 min and 10 min were kept for $\mathrm{Co}(\mathrm{II})$ and $\mathrm{Cr}$ (III) separately. The selected initial concentrations for both the adsorbates were shaken at orbital shaker at $120 \mathrm{rpm}$. The rest of the procedure was the same as discussed above. For obtaining the optimum value of initial concentration, the result was plotted as initial concentration $\left(\mathrm{mg} \mathrm{L}^{-1}\right)$ vs. $\mathrm{q}_{\mathrm{e}}$ and $\%$ removal.

\subsubsection{Effect of shaking speed.}

For optimizing the shaking speed, $50 \mathrm{~mL}$ of selected adsorbate solutions were taken with an initial concentration $60 \mathrm{ppm}$ and $40 \mathrm{ppm}$ for $\mathrm{Co}(\mathrm{II})$ and $\mathrm{Cr}(\mathrm{III})$, respectively. Other parameters, i.e., $\mathrm{pH}$, contact time, and adsorbent dose, have their optimized values as discussed in the above sections. The different mixtures were shaken at four different shaking speeds 60 $\mathrm{rpm}, 90 \mathrm{rpm}, 120 \mathrm{rpm}$, and $150 \mathrm{rpm}$. The rest of the procedure was the same as discussed in the section above. For obtaining the optimum value of shaking speed, the result was plotted as shaking speed (rpm) vs. qe and \% removal.

\section{Results and Discussion}

\subsection{Spectrophotometric determination.}

3.1.1. Spectrophotometric determination of $\mathrm{Co}(\mathrm{II})$.

Co(II) 's Spectrophotometric determination was made using an already reported method with little modifications [12]. To decide $\mathrm{Co}$ (II) concentration, solutions of various concentrations $(10,20,30,50$, and $60 \mathrm{ppm})$ were prepared. $3 \mathrm{~mL}$ from each solution, $1 \mathrm{~mL}$ of $1 \mathrm{M} \mathrm{HCl}$ solution, and $6 \mathrm{~mL}$ of acetone were added to the flask. The solution was mixed thoroughly, and at $680 \mathrm{~nm}$, the absorbance was measured. The result showed that absorbance increases with an increase in concentration.

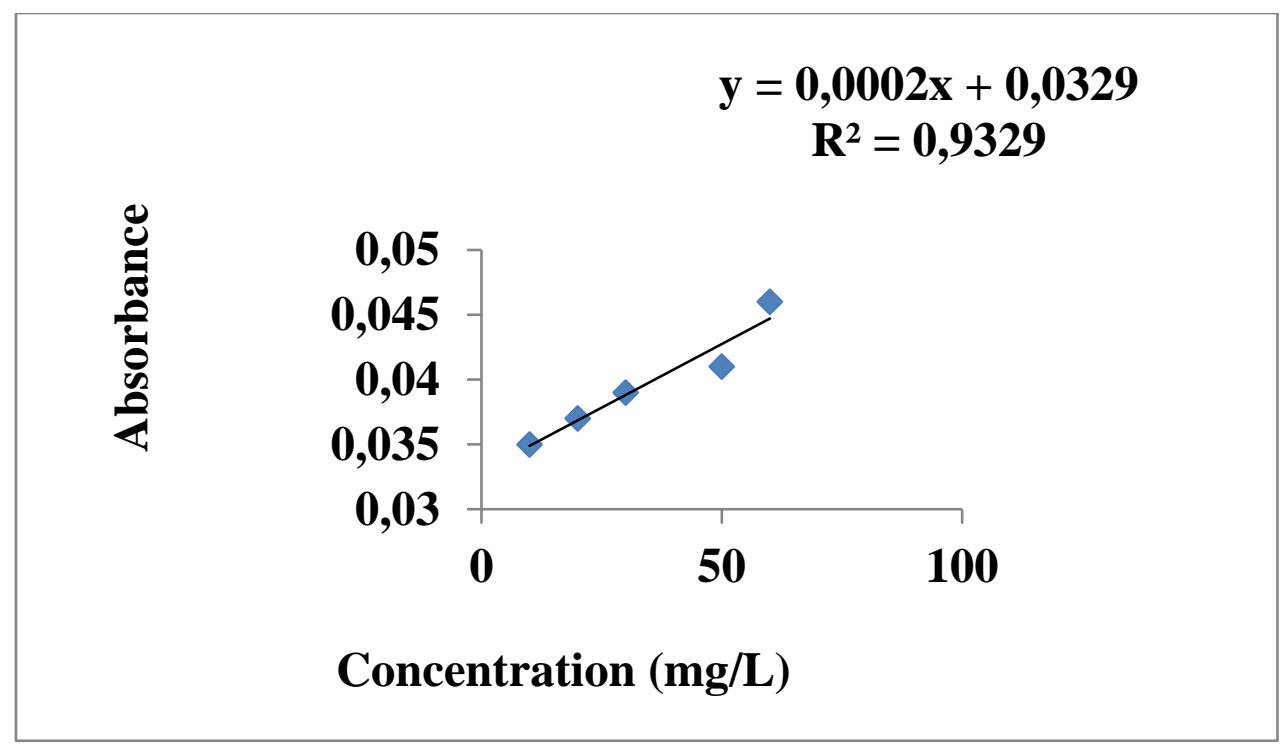

Figure 1. Spectrophotometric determination of $\mathrm{Co}(\mathrm{II})$. 


\subsubsection{Spectrophotometric determination of $\mathrm{Cr}$ (III).}

The Spectrophotometric determination of $\mathrm{Cr}$ (III) was made using the already reported method with little remodeling [9]. To determine the concentration of $\mathrm{Cr}$ (III) solution of various concentrations $(10,20,30,50$, and $60 \mathrm{ppm})$ was prepared. $5 \mathrm{~mL}$ of $\mathrm{Cr}$ (III) solutions were taken in a flask, and $5 \mathrm{~mL}$ of prepared $0.5 \% \mathrm{Na}_{2}$ EDTA solution were added to it to make a total of $10 \mathrm{~mL}$ mixture. The absorbance was measured at $552 \mathrm{~nm}$. The result depicts that absorbance increases with an increase in concentration.

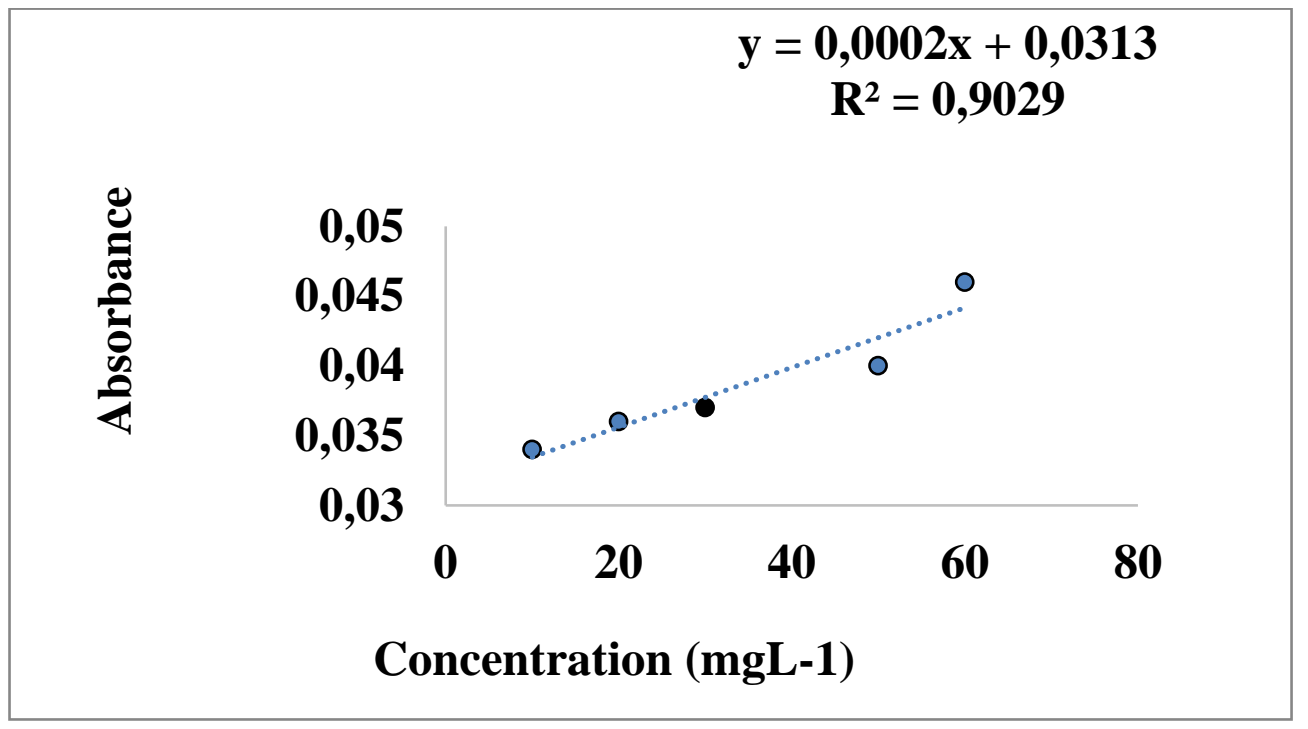

Figure 2. Spectrophotometric determination of $\mathrm{Cr}(\mathrm{III})$.

\subsection{Factors influencing the adsorption.}

\subsubsection{Effect of $\mathrm{pH}$.}

Effect of $\mathrm{pH}$ on adsorption of $\mathrm{Co}(\mathrm{II})$ and $\mathrm{Cr}$ (III) was studied in $\mathrm{pH}$ range (2-13). The result demonstrates that $\mathrm{Cr}$ (III) and $\mathrm{CO}$ (II) adsorption depends on $\mathrm{pH}$. The adsorption increases as $\mathrm{pH}$ increases and \% removal are maximum at $\mathrm{pH} 2$ for both $\mathrm{Co}(\mathrm{II})$ and $\mathrm{Cr}(\mathrm{III})$. The optimum value for both $\mathrm{Cr}$ (III) and $\mathrm{Co}$ (II) was attributed to the fact that a decrease in $\mathrm{pH}$ causing the conversion of the entire surface of adsorbent into the positive charge that leads to strong interaction that is shown in Fig: 3 (a) and (b). The result was plotted as $\mathrm{pH}$ vs. qe and \% removal [21].

Table 1. $\mathrm{pH}$ effect on adsorption of $\mathrm{CO}(\mathrm{II})$ and $\mathrm{Cr}(\mathrm{III})$.

\begin{tabular}{l|l|c|c|c|c}
\multirow{2}{*}{ S.No. } & \multirow{2}{*}{$\mathbf{p H}$} & \multicolumn{2}{|c|}{ Co (II) } & \multicolumn{2}{c}{$\mathbf{C r}$ (III) } \\
\cline { 3 - 6 } & $\mathbf{q e}(\mathbf{m g} / \mathbf{g})$ & \% Removal & $\mathbf{q e}(\mathbf{m g} / \mathbf{g})$ & \% Removal \\
\hline 1. & 2 & 9.75 & 97.5 & 8.25 & 82.5 \\
\hline 2. & 4 & 7.25 & 72.5 & 5.75 & 57.5 \\
\hline 3. & 5 & 7.25 & 72.5 & 5.75 & 32.5 \\
\hline 4. & 7 & 4.75 & 47.5 & 3.25 & 32.5 \\
\hline 5. & 8 & 4.75 & 47.5 & 3.25 & 32.5 \\
\hline 6. & 10 & 2.25 & 22.5 & 0.75 & 7.5 \\
\hline 7. & 12 & 2.25 & 22.5 & 0.75 & 7.5 \\
\hline 8. & 13 & 2.25 & 22.5 & 0.75 & 7.5
\end{tabular}

\subsubsection{Effect of adsorbent dose.}

Adsorption of $\mathrm{Co}(\mathrm{II})$ and $\mathrm{Cr}$ (III) with different adsorbent doses have been studied. The dosage varies from 0.1 to $0.5 \mathrm{~g}$. It saw that the adsorption capacity of $\mathrm{Co}$ (II) was increased with 
an increase in an adsorbent dose up to $0.3 \mathrm{~g}$ because more active sites on adsorbent are available. Then a saturation point is reached, and hence a decrease was observed beyond $0.3 \mathrm{~g}$. The effect for $\mathrm{Cr}$ (III) was linear, i.e., increased adsorption was observed with an increase in adsorbent dose, and maximum adsorption occurred at $0.5 \mathrm{~g}$. Hence adsorbent dose $0.3 \mathrm{~g}$ and $0.5 \mathrm{~g}$ was selected as an optimized adsorbent dose for further experiments, as shown in Fig: 4 (a) and (b). The result was plotted as adsorbent vs. qe and \% removal [22].

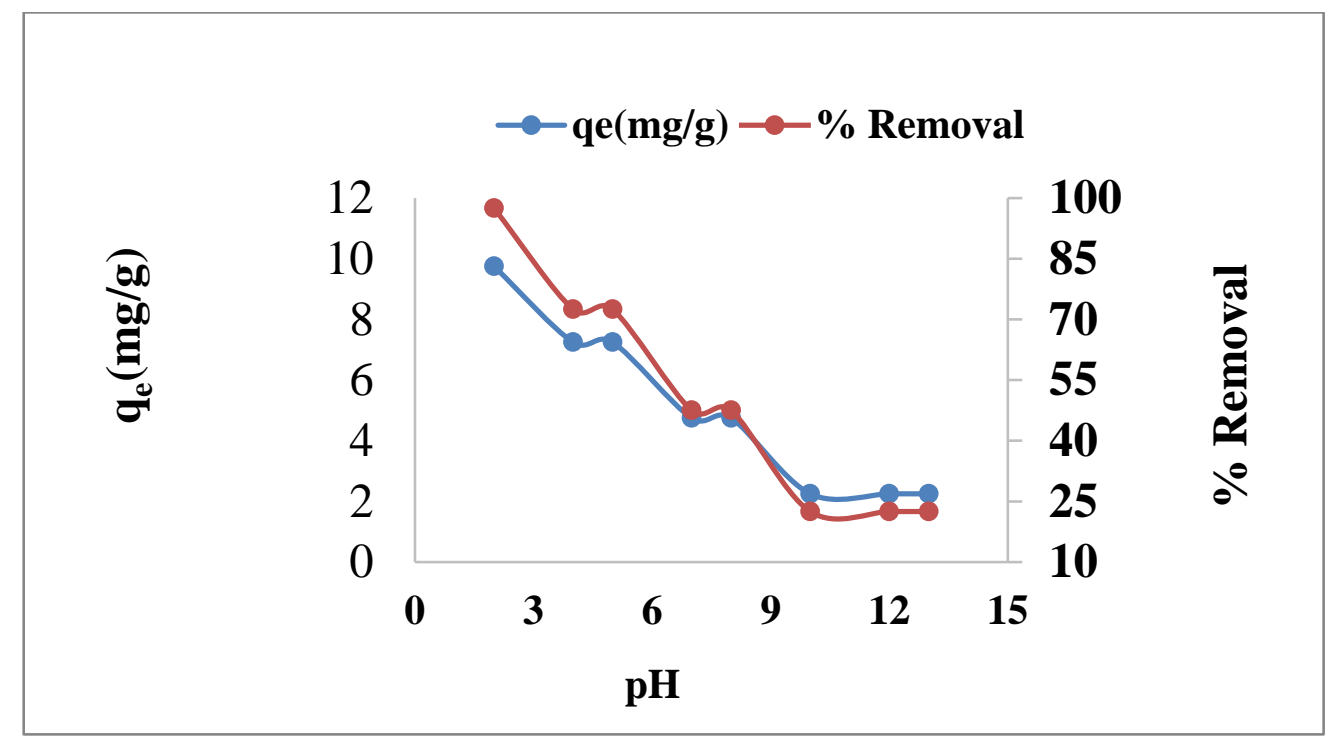

(a)

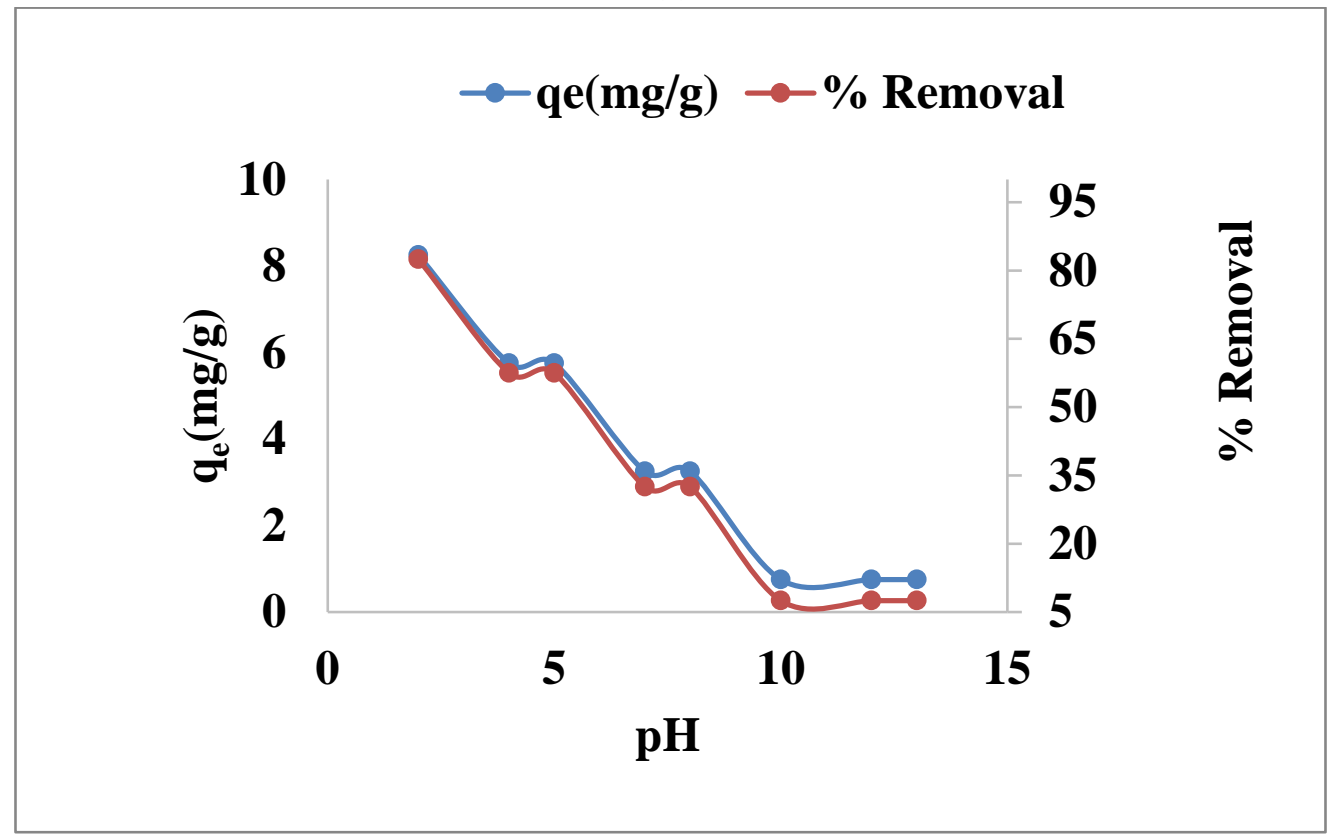

(b)

Figure 3. Effect of $\mathrm{pH}$ on the adsorption of (a) $\mathrm{Co}$ (II) and (b) $\mathrm{Cr}$ (III).

Table 2. Effect of adsorbent dose on $\mathrm{Co}$ (II) and $\mathrm{Cr}$ (III).

\begin{tabular}{l|c|c|c|c|c}
\multirow{2}{*}{ S.No. } & Adsorbent dose & \multicolumn{2}{|c|}{$\mathbf{C o}(\mathbf{I I})$} & \multicolumn{2}{c}{$\mathbf{C r}(\mathbf{I I I})$} \\
\cline { 3 - 6 } & $\mathbf{( g )}$ & $\mathbf{q}$ & $\mathbf{\%}$ & $\mathbf{q e}$ & $\mathbf{\%}$ \\
& 0.1 & 7.25 & 72.5 & 15 & 50 \\
\hline $\mathbf{1 .}$ & 0.2 & 7.25 & 72.5 & 17.8 & 55.6 \\
\hline $\mathbf{2 .}$ & 0.3 & 9.75 & 97.5 & 18.7 & 61.11 \\
\hline $\mathbf{3 .}$ & 0.4 & 4.75 & 47.5 & 19.3 & 72.22 \\
\hline $\mathbf{4 .}$ & 0.5 & 2.25 & 22.5 & 19.44 & 72.22
\end{tabular}




\subsubsection{Effect of contact time.}

To study $\mathrm{Co}$ (II) and $\mathrm{Cr}$ (III) 's adsorption capacity, various contact timings ranging from $10-60$ min were selected. It was found that $\mathrm{Co}$ (II) adsorption rises with an increase in contact time, and maximum adsorption occurs at $20 \mathrm{~min}$ of $\mathrm{Co}$ (II). For $\mathrm{Cr}$ (III), adsorption was maximum at $10 \mathrm{~min}$, adsorption increases when contact time increases as shown in Fig: 5 (a) and (b).as a result, $20 \mathrm{~min}$ was selected as optimized contact time for further experimental parameters. The result was plotted as contact time vs. qe and \% removal [23].

\subsubsection{Effect of initial concentration.}

The concentration effect was investigated in the range of 20-100 ppm for adsorbate solutions of $\mathrm{Cr}(\mathrm{III})$ and $\mathrm{CO}(\mathrm{II})$. The optimized $\mathrm{pH} 2$, adsorbent dose $(0.3 \mathrm{~g}$ and $0.5 \mathrm{~g}$, respectively), and contact time were used during the experiment. The adsorption increases with an increase in initial concentration; however, the percent removal decreases at higher concentrations. Maximum adsorption occurs at $60 \mathrm{ppm}$ for both $\mathrm{Cr}$ (III) and $\mathrm{CO}$ (II), as shown in Fig: 6 (a) and (b). The decrease in adsorption at higher concentrations is due to the saturation of active sites. The result was plotted as initial concentration vs. qe and \% removal [24].

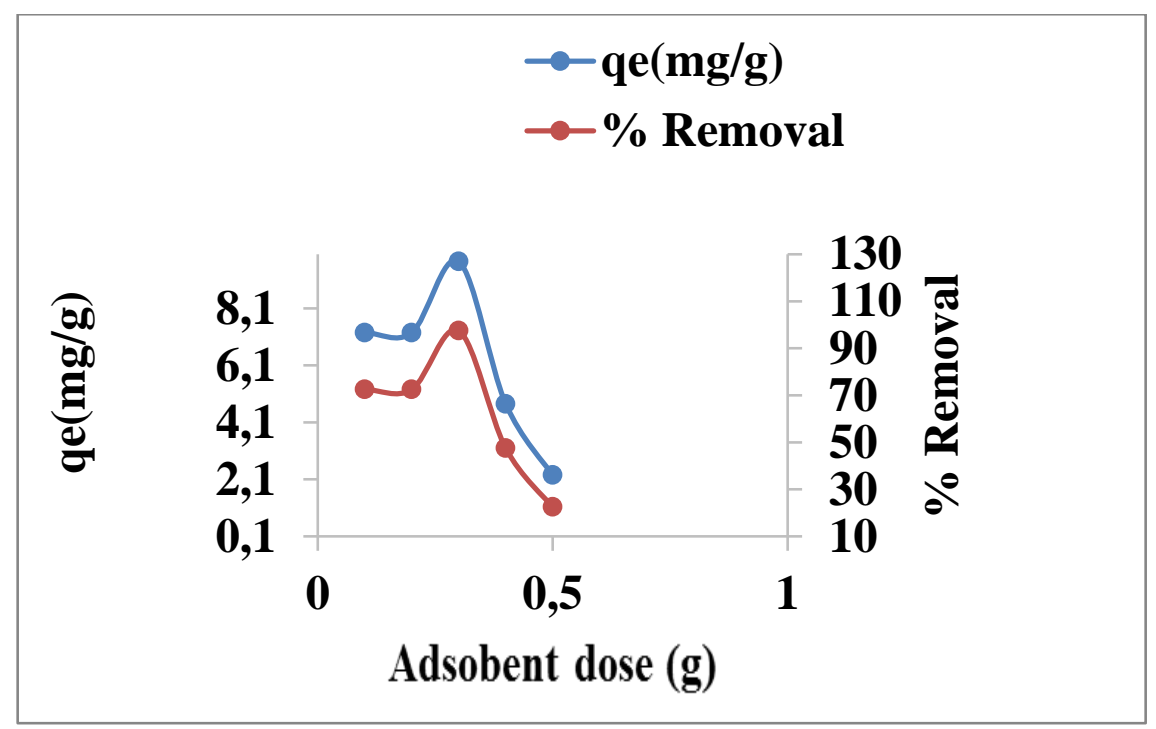

(a)

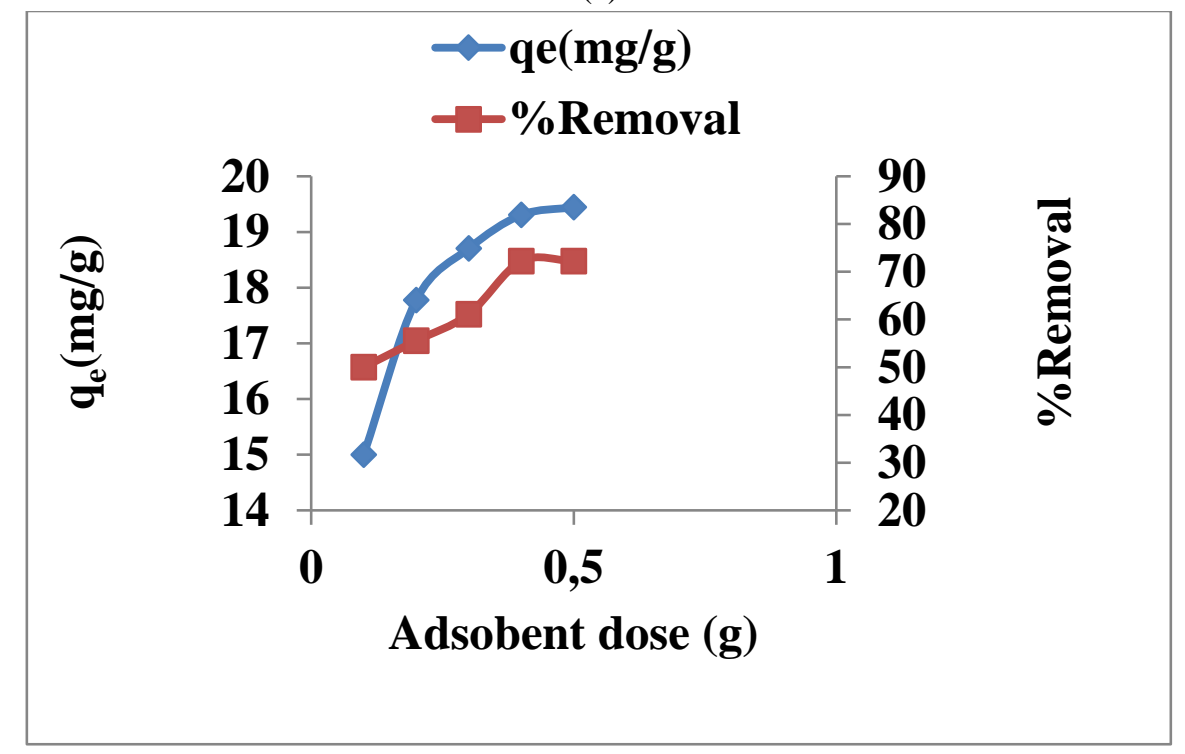

(b) 
Figure 4. Effect of adsorbent dose on (a) $\mathrm{Co}(\mathrm{II})$ and (b) $\mathrm{Cr}$ (III).

Table 3. Effect of contact time on $\mathrm{Co}$ (II) and $\mathrm{Cr}$ (III).

\begin{tabular}{l|c|c|c|c|c}
\multirow{2}{*}{ S.NO } & \multirow{2}{*}{ Time (min) } & \multicolumn{2}{|c}{ Co (II) } & \multicolumn{2}{c}{ Cr (III) } \\
\cline { 3 - 6 } & 10 & $\mathbf{q}_{\mathbf{e}}(\mathbf{m g} / \mathbf{g})$ & \% removal & $\mathbf{q}_{\mathbf{e}}(\mathbf{m g} / \mathbf{g})$ & \% removal \\
\hline 1 & 2.75 & 47.5 & 8.25 & 82.5 \\
\hline 2 & 20 & 9.75 & 97.5 & 5.75 & 57.5 \\
\hline 3 & 30 & 2.25 & 22.5 & 5.75 & 57.5 \\
\hline 4 & 40 & 7.25 & 72.5 & 3.25 & 32.5 \\
\hline 5 & 50 & 4.75 & 47.5 & 0.75 & 7.5 \\
\hline 6 & 60 & 2.25 & 22.5 & 0.75 & 7.5
\end{tabular}

\subsubsection{Effect of shaking speed.}

The effect of shaking speed was studied at various shaking speeds $(60,90,120$, and 150 rpm). The other parameters were taken as optimized. It was found that adsorption of $\mathrm{Cr}$ (III) and $\mathrm{CO}$ (II) increases with shaking speed because of the number of collisions of adsorbate and biosorbent increases. The adsorption is maximum at $120 \mathrm{rpm}$ for $\mathrm{Cr}(\mathrm{III})$, and after this, a saturation of active sites occurs. The increase in adsorption was linear with shaking speed for Co (II). Hence the $150 \mathrm{rpm}$ and $120 \mathrm{rpm}$ were selected as optimum shaking speed for $\mathrm{Cr}$ (III) and $\mathrm{CO}$ (II) separately [25].

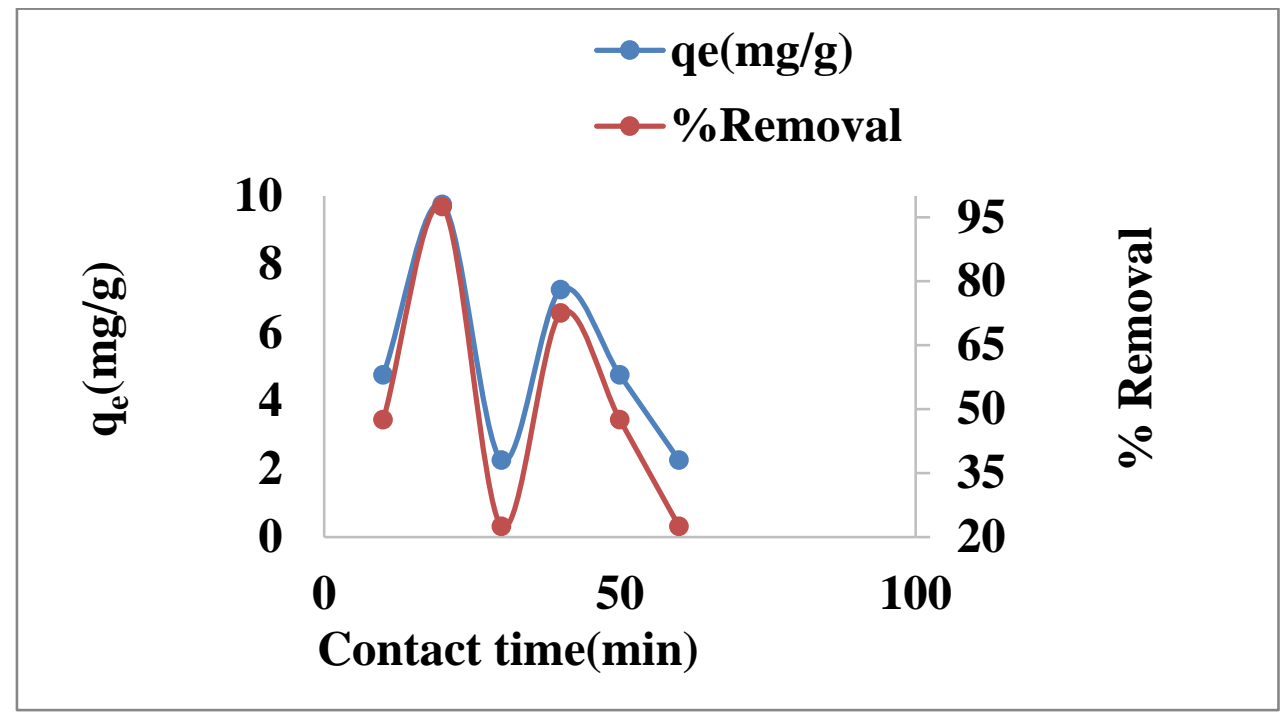

(a)

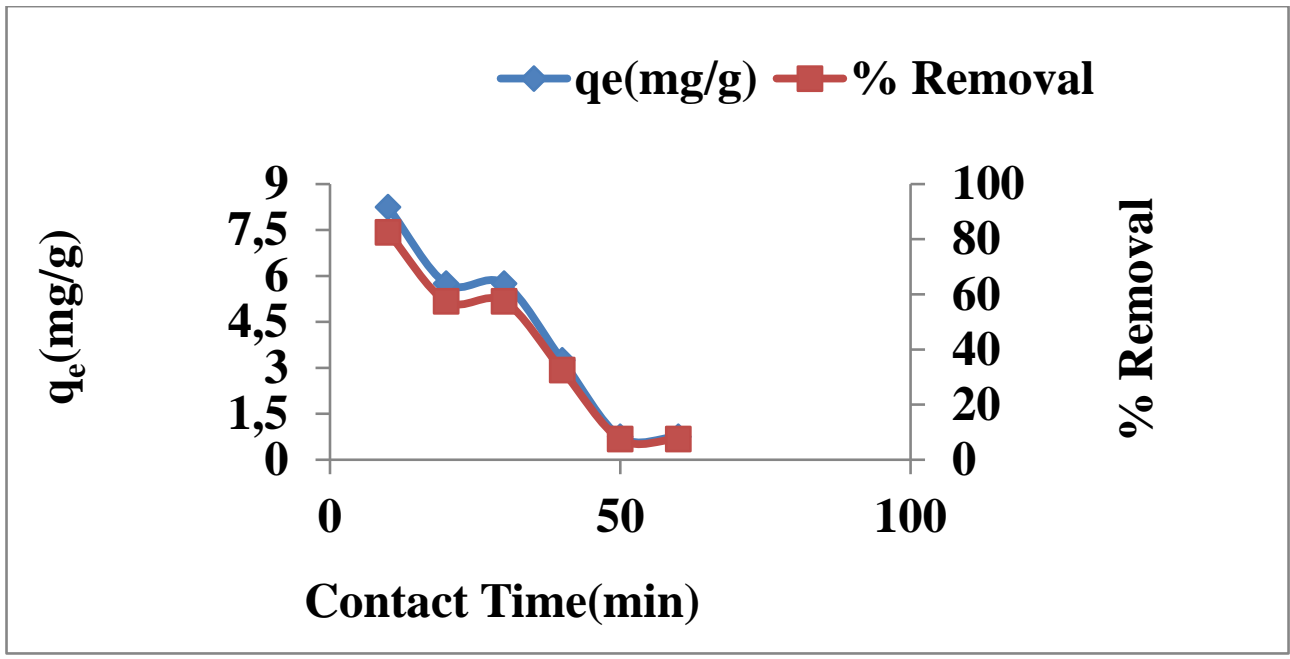

(b)

Figure 5. Effect of contact time on the adsorption of (a) $\mathrm{Co}$ (II) (b) $\mathrm{Cr}$ (III). 
Table 4. Effect of initial concentration on $\mathrm{Co}(\mathrm{II})$ and $\mathrm{Cr}(\mathrm{III})$.

\begin{tabular}{l|c|c|c|c|c}
\multirow{2}{*}{ S.No. } & \multirow{2}{*}{$\begin{array}{c}\text { Shaking } \\
\text { speed(rpm) }\end{array}$} & \multicolumn{2}{|c|}{ Co (II) } & \multicolumn{2}{c}{ Cr (III) } \\
\cline { 3 - 6 } & 60 & 9,75 & 48.75 & 10.75 & 53.75 \\
\hline 1 & 90 & 12.25 & 61.25 & 15.75 & 78.75 \\
\hline 2 & 120 & 14.75 & 73.75 & 18.25 & 91.25 \\
\hline 3 & 150 & 17.25 & 86.25 & 13.25 & 66.25
\end{tabular}

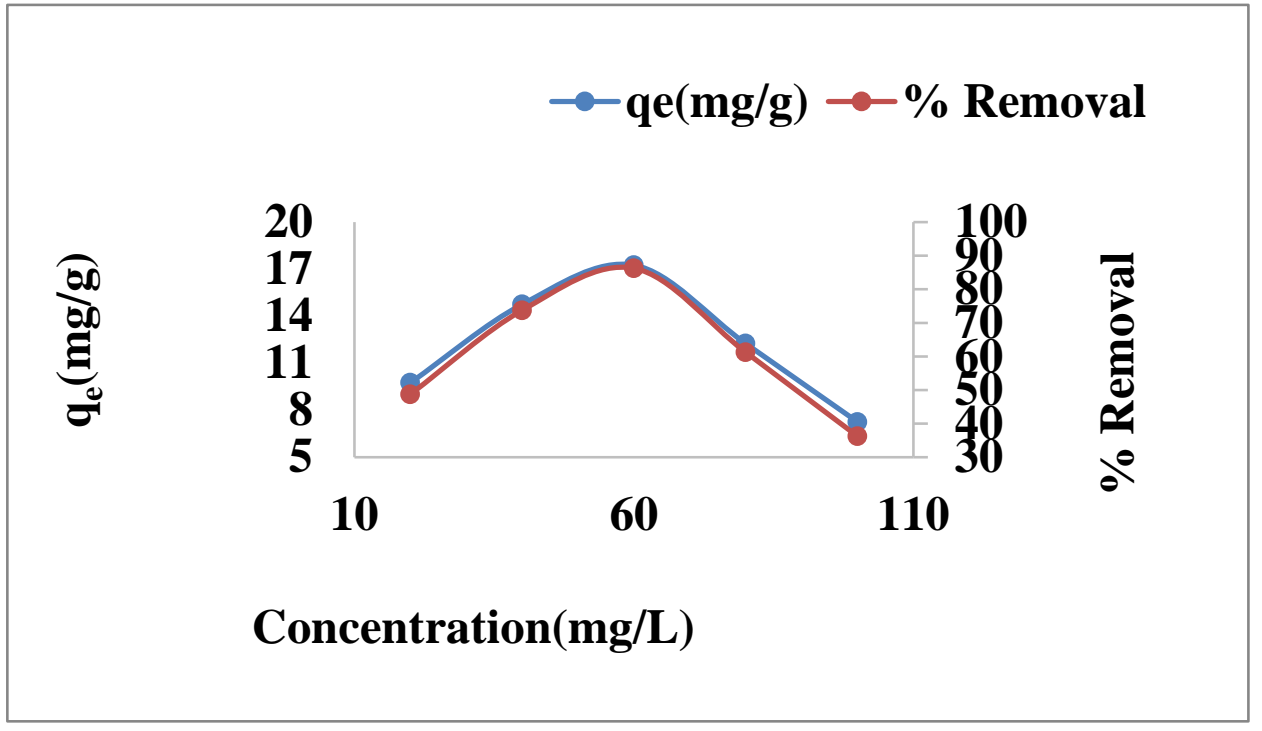

(a)

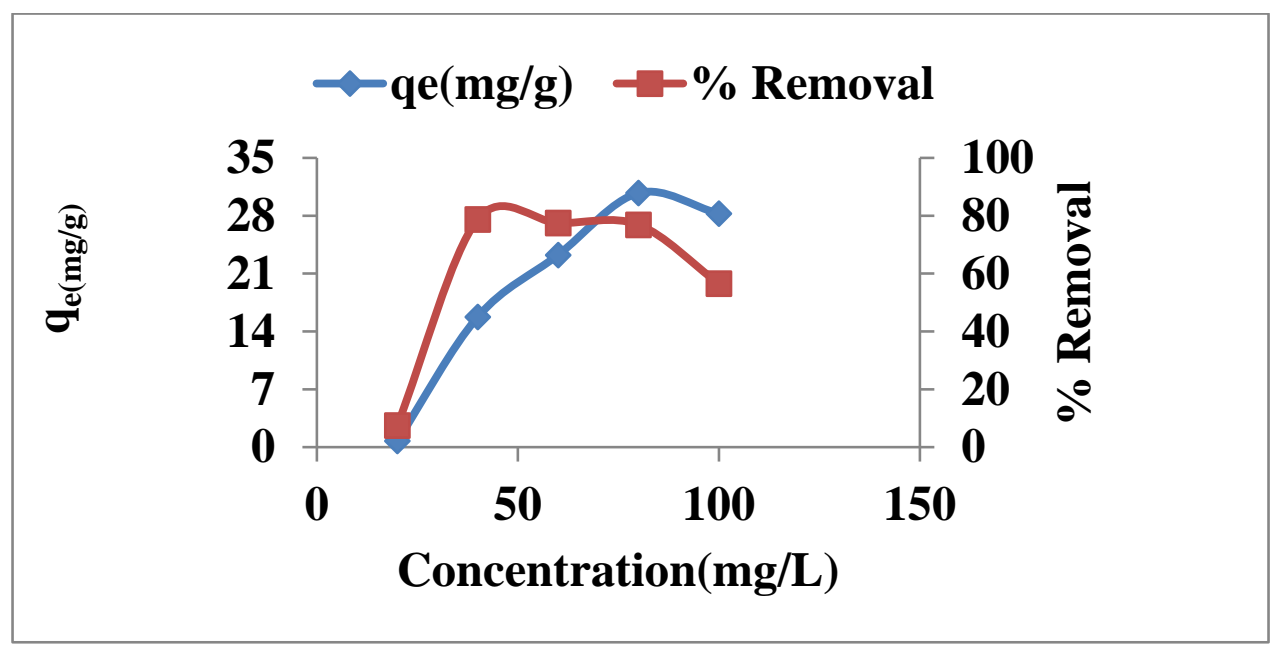

(b)

Figure 6. Effect of initial concentration on (a) $\mathrm{Co}$ (II) and (b) $\mathrm{Cr}$ (III).

Table 5. Effect of shaking speed on $\mathrm{Co}(\mathrm{II})$ and $\mathrm{Cr}$ (III).

\begin{tabular}{l|c|c|c|c|c}
\multirow{2}{*}{ S.NO } & Shaking & \multicolumn{2}{|c|}{ Co (II) } & \multicolumn{2}{c}{ Cr (II) } \\
\cline { 3 - 6 } & speed(rpm) & $\mathbf{q e}_{\mathbf{e}}(\mathbf{m g} / \mathbf{g})$ & \% Removal & $\mathbf{q e}(\mathbf{m g} / \mathbf{g})$ & \% Removal \\
\hline 1 & 60 & 9.75 & 48.75 & 10.75 & 53.75 \\
\hline 2 & 90 & 12.25 & 61.25 & 15.75 & 78.75 \\
\hline 3 & 120 & 17.25 & 86.25 & 18.25 & 91.25 \\
\hline 4 & 150 & 17.25 & 86.25 & 13.25 & 66.25
\end{tabular}




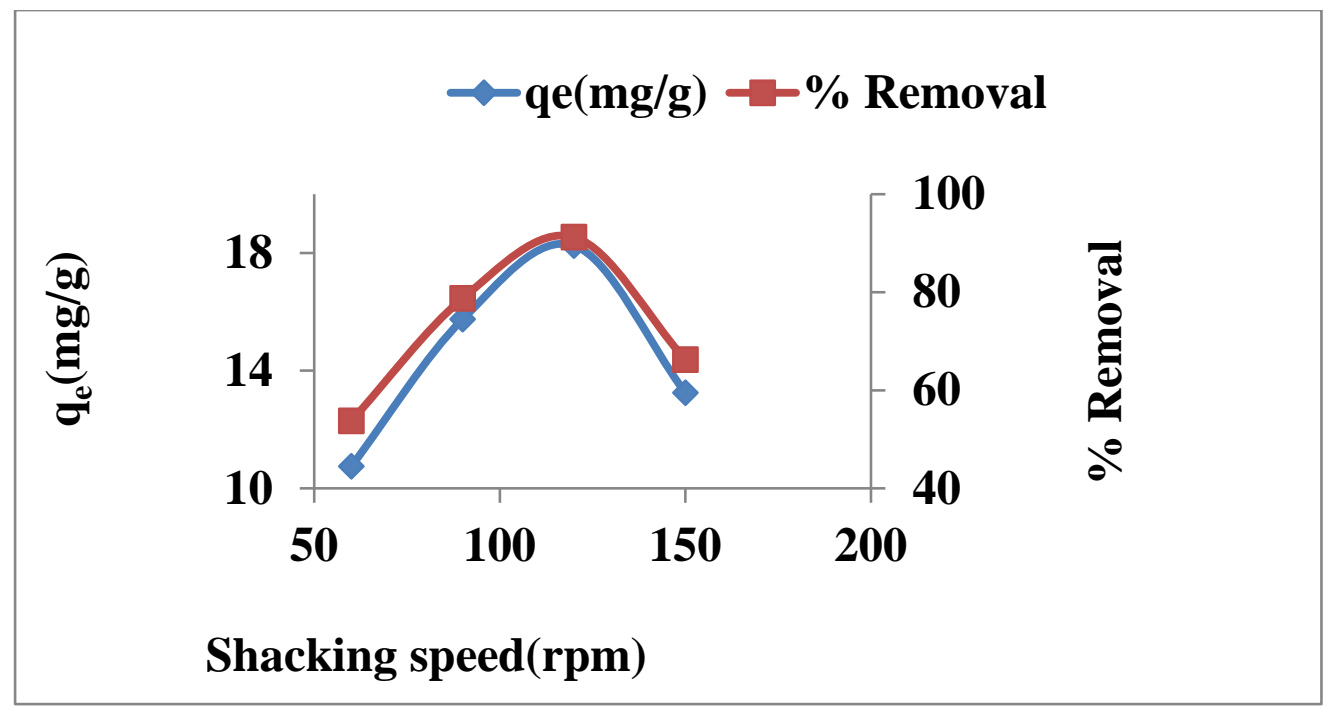

(a)

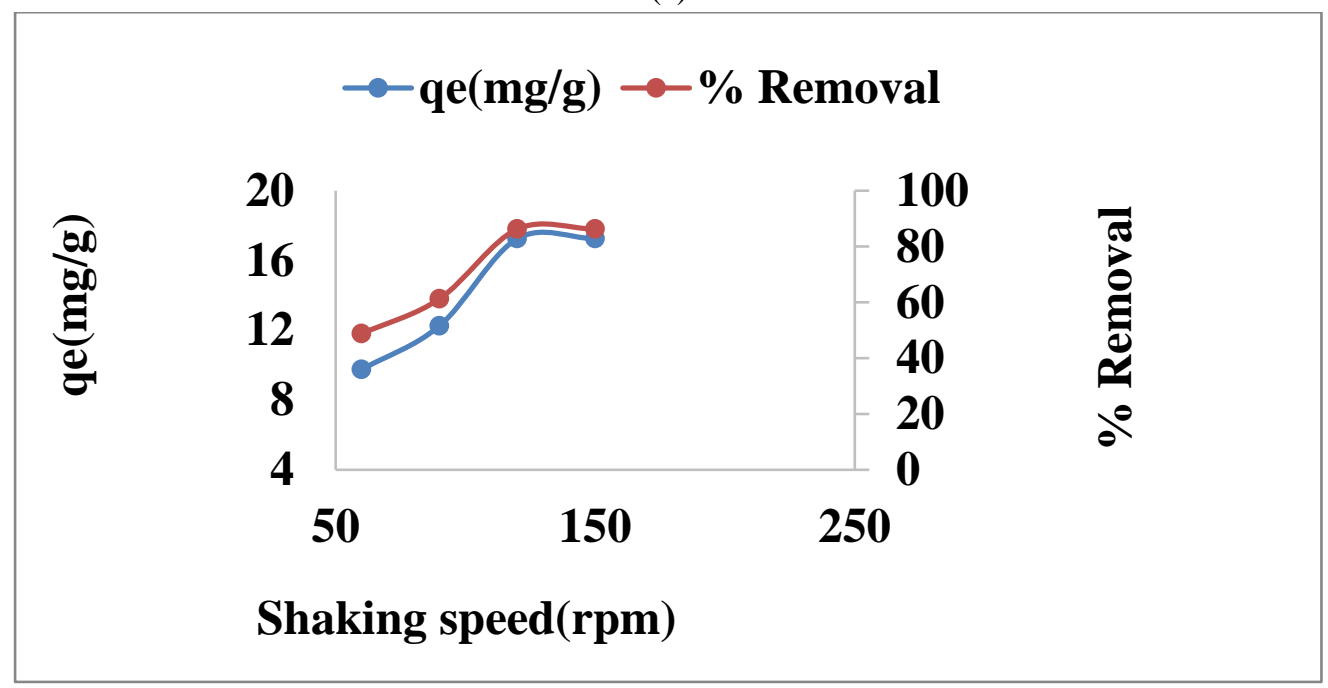

(b)

Figure 7. Effect of Shaking speed on (a) $\mathrm{Co}(\mathrm{II})$ and (b) $\mathrm{Cr}$ (III).

\section{Conclusions}

Various adsorption techniques have been studied to eliminate $\mathrm{Cr}$ (III) and $\mathrm{CO}$ (II) onto lemon leaves. The present study shows the $\mathrm{pH}$, adsorbent dosage, contact time, initial concentration, and shaking speed affecting the adsorption of both adsorbates $\mathrm{Co}$ (II) and (b) $\mathrm{Cr}$ (III). The maximum adsorption occurs at $\mathrm{pH} 2$ for both adsorbates. It was found that adsorption of selected adsorbates increased with adsorbent dose and got maximum at optimum adsorbent dose values ( $0.3 \mathrm{~g}$ and $0.5 \mathrm{~g}$ for Co (II) and $\mathrm{Cr}$ (III), respectively). The biosorption capacity of biomass increases with initial concentration, and maximum adsorption has been found at 40 and $60 \mathrm{ppm}$ for $\mathrm{C} 0$ (II) and $\mathrm{Cr}$ (III), respectively. The optimum contact time for Co (II) was $10 \mathrm{~min}$, and that for $\mathrm{Cr}$ (III) was $20 \mathrm{~min}$. It was also found that adsorption was increased as an increase in shaking speed occur and maximum adsorption occurred at $150 \mathrm{rpm}$ and 120 rpm for $\mathrm{Cr}$ (III) and $\mathrm{CO}$ (II), respectively. The results of various parameters confirmed that the selected adsorbent is highly suitable for the adsorption of selected adsorbate from water.

\section{Funding}

This research received no external funding. 


\section{Acknowledgments}

This research has no acknowledgment.

\section{Conflicts of Interest}

The authors declare no conflict of interest.

\section{References}

1. Aborode Abdullahi, T.; Benedicta, D.; Abigail Owusuwaa, G.; Opoku, E. Isotherms, Kinetics, Equilibrium, and Thermodynamic Studies on the Uptake of Hexavalent Chromium Ions from Aqueous Solution Using Synthetic Hydroxyapatite. Advanced Journal of Chemistry-Section B 2020, 2, 214-225, https://doi.org/10.22034/ajcb.2020.113974.

2. Al, S.; Alakhras, F.; Al-Mazaideh, G. Sorption of Cobalt (II) Ions from Aqueous Solutions Using Chemically Modified Chitosan. Global Nest Journal 2018, 20, 182-189, https://doi.org/10.30955/gnj.002804.

3. Santos, I.C.; Mesquita, R.B.R.; Rangel, A.O.S.S. Membrane-based Separation in Flow Analysis for Environmental and Food Applications. Separation \& Purification Reviews 2020, 49, 37-54, https://doi.org/10.1080/15422119.2018.1506810.

4. Tizro, S.; Baseri, H. Removal of Cobalt Ions from Contaminated Water Using Magnetite Based Nanocomposites: Effects of Various Parameters on the Removal Efficiency. Journal of Water and Environmental Nanotechnology 2017, 2, 174-185, https://doi.org/10.22090/jwent.2017.03.005.

5. Ntshoko, Z. Low cost pineapple peel biosorbent for the removal of aqueous cobalt from textile wastewater effluent. PhD diss., Cape Peninsula University of Technology, 2020.

6. Vakh, C.; Evdokimova, E.; Pochivalov, A.; Moskvin, L.; Bulatov, A. A novel flow injection chemiluminescence method for automated and miniaturized determination of phenols in smoked food samples. Food Chemistry 2017, 237, 929-935, https://doi.org/10.1016/j.foodchem.2017.06.049.

7. Masilo, Joy. Investigation of the hydrogen spillover effect in platinum promoted cobalt/hollow carbon spheres. PhD diss. 2019.

8. Zhou, J.; Wang, Y.; Wang, J.; Qiao, W.; Long, D.; Ling, L. Effective removal of hexavalent chromium from aqueous solutions by adsorption on mesoporous carbon microspheres. Journal of Colloid and Interface Science 2016, 462, 200-207, https://doi.org/10.1016/j.jcis.2015.10.001.

9. Liu, Q.; Kim, J.; Cui, T. A highly sensitive photoelectrochemical sensor with polarity-switchable photocurrent for detection of trace hexavalent chromium. Sensors and Actuators B: Chemical 2020, 317, https://doi.org/10.1016/j.snb.2020.128181.

10. Luo, W.; Lu, Y.; Wang, G.; Shi, Y.; Wang, T.; Giesy, J.P. Distribution and availability of arsenic in soils from the industrialized urban area of Beijing, China. Chemosphere 2008, 72, 797-802, https://doi.org/10.1016/j.chemosphere.2008.03.003.

11. Gagic, M.; Kociova, S.; Smerkova, K.; Michalkova, H.; Setka, M.; Svec, P.; Pribyl, J.; Masilko, J.; Balkova, R.; Heger, Z.; Richtera, L.; Adam, V.; Milosavljevic, V. One-pot synthesis of natural amine-modified biocompatible carbon quantum dots with antibacterial activity. Journal of Colloid and Interface Science 2020, 580, 30-48, https://doi.org/10.1016/j.jcis.2020.06.125.

12. Baek, Y.; Das, A.; Zheng, S.-L.; Reibenspies, J.H.; Powers, D.C.; Betley, T.A. C-H Amination Mediated by Cobalt Organoazide Adducts and the Corresponding Cobalt Nitrenoid Intermediates. Journal of the American Chemical Society 2020, 142, 11232-11243, https://doi.org/10.1021/jacs.0c04252.

13. Isozumi, H.; Kubota, K.; Tatara, R.; Horiba, T.; Hida, K.; Matsuyama, T.; Yasuno, S.; Komaba, S. Impact of Newly Developed Styrene-Butadiene-Rubber Binder on the Electrode Performance of High-Voltage LiNi0.5Mn1.5O4 Electrode. ACS Applied Energy Materials 2020, 3, 7978-7987, https://doi.org/10.1021/acsaem.0c01334.

14. Danzeisen, R.; Williams, D.L.; Viegas, V.; Dourson, M.; Verberckmoes, S.; Burzlaff, A. Bioelution, Bioavailability, and Toxicity of Cobalt Compounds Correlate. Toxicological Sciences 2020, 174, 311-325, https://doi.org/10.1093/toxsci/kfz249.

15. Tounsadi, H.; Khalidi, A.; Abdennouri, M.; Barka, N. Biosorption potential of Diplotaxis harra and Glebionis coronaria L. biomasses for the removal of $\mathrm{Cd}(\mathrm{II})$ and $\mathrm{Co}$ (II) from aqueous solutions. Journal of Environmental Chemical Engineering 2015, 3, 822-830, https://doi.org/10.1016/j.jece.2015.03.022.

16. Oguz, E.; Ersoy, M. Biosorption of cobalt(II) with sunflower biomass from aqueous solutions in a fixed bed column and neural networks modelling. Ecotoxicology and Environmental Safety 2014, 99, 54-60, https://doi.org/10.1016/j.ecoenv.2013.10.004.

17. Yu, H.; Pang, J.; Ai, T.; Liu, L. Biosorption of $\mathrm{Cu} 2+$, $\mathrm{Co} 2+$ and $\mathrm{Ni2}+$ from aqueous solution by modified corn silk: Equilibrium, kinetics, and thermodynamic studies. Journal of the Taiwan Institute of Chemical Engineers 2016, 62, 21-30, https://doi.org/10.1016/j.jtice.2016.01.026. 
18. kbari, M.; Hallajisani, A.; Keshtkar, A.R.; Shahbeig, H.; Ali Ghorbanian, S. Equilibrium and kinetic study and modeling of $\mathrm{Cu}$ (II) and $\mathrm{Co}$ (II) synergistic biosorption from $\mathrm{Cu}$ (II)-Co(II) single and binary mixtures on brown algae C. indica. Journal of Environmental Chemical Engineering 2015, 3, 140-149, https://doi.org/10.1016/j.jece.2014.11.004.

19. Gavazov, K.B.; Hagarová, I.; Halko, R.; Andruch, V. Recent advances in the application of nanoparticles in cloud point extraction. Journal of Molecular Liquids 2019, 281, 93-99, https://doi.org/10.1016/j.molliq.2019.02.071.

20. Autere, A.; Jussila, H.; Dai, Y.; Wang, Y.; Lipsanen, H.; Sun, Z. Nonlinear Optics with 2D Layered Materials. Advanced Materials 2018, 30, https://doi.org/10.1002/adma.201705963.

21. Ateia, M.; Helbling, D.E.; Dichtel, W.R. Best Practices for Evaluating New Materials as Adsorbents for Water Treatment. ACS Materials Letters 2020,1532 , https://doi.org/10.1021/acsmaterialslett.0c00414.

22. Politaeva, N.; Smyatskaya, Y.; Al Afif, R.; Pfeifer, C.; Mukhametova, L. Development of Full-Cycle Utilization of Chlorella sorokiniana Microalgae Biomass for Environmental and Food Purposes. Energies 2020, 13, https://doi.org/10.3390/en13102648.

23. Vladimirov, I.A.; Mukhametova, L.; Yamashkin, M.V. Some aspects of use of organic containing waste for electrical and thermal energy generation. E3S Web of Conferences 2020, 178, https://doi.org/10.1051/e3sconf/202017801084.

24. Sinitsyn, A.; Oleg, S.; Timur, A.; Nikolay, M. Methodology for assessing technological efficiency and safety at the enterprise for production of reinforced concrete structures. E3S Web of Conferences 2020, 178, https://doi.org/10.1051/e3sconf/202017801073.

25. Shen, Y. A review on hydrothermal carbonization of biomass and plastic wastes to energy products. Biomass and Bioenergy 2020, 134, https://doi.org/10.1016/j.biombioe.2020.105479. 